\title{
Evolution of a gadfly
}

\section{Washington}

THERE was something distinctly wrong with the picture: Bernadine Healy, the director of the US National Institutes of Health (NIH), was testifying last week before a congressional committee about the dangers of misusing genetic information. Beside her and echoing her concerns was Nobel Laureate James Watson, director of the US human genome project. Gene therapy pioneer W. French Anderson was nodding agreement on the right.

And sitting just behind them, having orchestrated the whole thing, was Jeremy Rifkin - biotechnology heretic, sworn enemy of genetic release, filer of countless lawsuits, general science pest.

Only a few years ago, prominent scientists were refusing to appear on the same panel as Rifkin, were calling him a "modern-day Luddite", a "fearmonger", a "nut". Now they support his legislation, endorse many of his concerns, sometimes even hard as it is to believe - talk to him.

Have researchers and policy-makers in US science finally given in to pressure from a self-described radical? Or is it Rifkin himself who has gone soft?

The answer, not surprisingly, turns out to be a little bit of both. Fifteen years of Rifkin's lawsuits, petitions, legislation, press-conferences and general harassment has finally made a dent on the gene scien- tists. "He's an activist — he's trying to push a point of view that biotech is rushing forward at a pace too fast for society," says Anderson. "But I agree with his ends, if not his means. As always, he can't resist taking potshots at NIH in public, but in private he is much more reasonable. He's

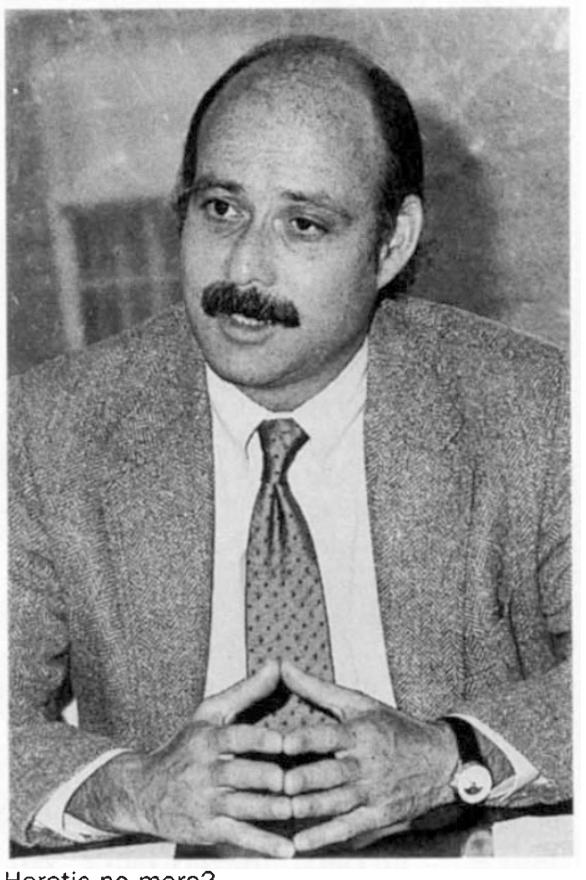

trying very hard to develop a consensus and a basis for cooperation.'

And, indeed, Rifkin is showing a new desire to work with - if not in - the system. He corresponded with Watson for a year before Watson agreed to support, in principle, a genetic privacy bill that Rifkin drafted and Representative John Conyers (Democrat, Michigan) introduced last year. "It is not unimportant that we got those people in that room [last week]," Rifkin says. "They didn't have to come. This is our first common ground after 15 years of adversity."

But politics speaks louder than philosophy, and last week's extraordinary scene may owe more to Rifkin's congressional acumen than any great shifting of the scientific status quo. If Healy, Watson and David Galas, the head of the genome project at the Department of Energy, were testifying as if their funding depended on it, that is largely because much of it does. In part because of Rifkin's lobbying, Congress has inserted language into the NIH and DOE genome budgets that requires the agencies to spend at least four per cent of their allocations on research on the social and ethical issues of genetic manipulation. Whether or not the officials personally feel as strongly as Rifkin does about the dangers of genetic information, they are being paid to take them seriously.

Nevertheless, it is not insignificant that the genome project's policy-makers were saying the sort of things last week that

\section{Global warming meets genetic engineering}

\section{Washington}

THERE is really no plausible connection between global warming and genetic engineering. But after about half an hour with Jeremy Rifkin one is not so sure. Rifkin, the president of the anti-biotechnology Foundation on Economic Trends, also happens to be the president of the Greenhouse Crisis Foundation, a threeyear old organization that shares the same staff and modest Washington office. Critics have derided him as an opportunist who has made a career of jumping on bandwagons. Certainly his groups' cryptic names do nothing to suggest any special issue loyalty, nor, for that matter, does his entry into global warming activism at the peak of its popularity.

But Rifkin, if nothing else, makes great intellectual arguments. Global warming, he says, would raise the temperature and decrease the rainfall in many agricultural regions. Keeping those areas productive means finding plants that can handle the harsh new conditions. "We won't be able to wait for evolution", he says. "We're going to need genetic engineering." Because he is generally against the production and release of genetically engineered plants (and animals), it is in his interest to try to prevent an environmental situation that demands them. Q.E.D.

These are some of the other current issues that have drawn Rifkin's attention - and lawsuits:

- Genetic information: The Rifkin-drafted Human Genome Privacy Act, introduced in the House of Representatives last year, would forbid government agencies and their contractors from disclosing any individual's genetic information without written consent, with the exception of medical emergencies and criminal investigations. Notably, it does not address what the agency does with the data internally. Rifkin expects the bill pass the House this session, although there is as yet no matching legislation in the Senate. - Bovine and human growth hormones: Despite government studies to the contrary, Rifkin believes that growth hormones have not been proved safe, and may have harmful side-effects, such as 'cow burnout' and economic damage to small dairy farmers. His group coordinated a lobbying, legal and grassroots campaign last year that resulted in bans on bovine growth hormone in the dairy states of Wisconsin and Minnesota.

- Animal patenting: Patenting animals makes them legally "indistinguishable from microwave ovens," Rifkin says. His group is lobbying in the United States and Europe to prevent patenting of genetically-modified animals. Although the United States granted one patent (for the 'Harvard mouse') three years ago, and the European Patent Office has announced its intention to do the same (see Nature 353, 589; 17 October 1991), Rifkin points out that no subsequent US patents have been granted, despite more than a hundred applications in the queue. - Genetic release: Since his first success in delaying government-approved plans to test a genetically engineered microbe that protects plants from frost, Rifkin has fought for increased precautions in releasing genetically modified organisms into the environment.

- Global Warming: The Greenhouse Crisis Foundation organizes public education programmes and lobbies for increased research and legislation for safe energy and renewable agriculture. C.A. 